\title{
Cartesian Aseity in the Third Meditation
}

\author{
Landon McBrayer \\ University of Utah
}

\begin{abstract}
In his Mediations, Descartes introduces a notion of divine aseity that, given some other commitments about causation and knowledge of the divine, must be different than the Scholastic notion of aseity exemplified by Aquinas. Unfortunately for Descartes some commentators - contemporaries of both his and ours-have thought his "positive" notion of aseity to be incoherent. I argue that properly understanding the structure of the theistic argument in which the notion of aseity plays a role, along with considering Descartes broader views on causation, shows that the Cartesian notion of divine aseity is not just coherent but fits well into Descartes's overall conception of the divine. While he does innovate on Aquinas's notion of aseity in an interesting way, Descartes's view turns out to be very different than the view often attributed to him.
\end{abstract}

The notion that something can exist a se (of/through itself) is central to Descartes's overall metaphysics of causation. In the Meditations, divine aseity plays the role of explaining not only God's existence but ultimately the existence of everything else apart from God. Yet in the Meditations proper, as well as in the early Replies, Descartes does little to clarify (much less defend) exactly what his view of divine aseity is and how it might differ from the sort of aseity commonly posited by the Scholastics. Stated provisionally, the classical "negative" view of aseity takes God to be an uncaused cause, while a "positive" view takes God to be self-caused in some way (e.g., God is his own efficient cause). In the First Replies, Descartes looks to endorse the positive view of aseity by noting that "it is this sense alone which is employed in my argument" (AT 7:110; CSM 2:79). This being so, in the Objections from his contemporaries Descartes is twice accused of positing, in the Third Meditation, a "positive" notion of divine aseity that is either too strong and thus superfluous (AT 7:95; CSM 2:68) or contradictory when applied to God (AT 7:212; CSM 2:149). ${ }^{1}$ Despite Descartes's later attempts to assuage this worry and clarify his position, the positive aseity charge-that Descartes indeed endorses the positive notion-has not

\footnotetext{
1 All citations from Descartes are in-text. "AT" refers to C. Adam and P. Tannery, eds., Oeuvres de Descartes (Paris: J. Vrin/CNRS, 1964-1976); "CSM" refers to J. Cottingham, R. Stoothoff, and D. Murdoch, eds., The philosophical Writings of Descartes, vols I and II (Cambridge: Cambridge University Press, 1985); "CSMK" refers to vol. III, The Correspondence, by the same translators plus A. Kenny (Cambridge: Cambridge University Press, 1991).
}

Journal of Analytic Theology, Vol. 6, December 2018

10.12978/jat.2018-6.110013120217

(C) 2018 Landon McBrayer • (C) 2018 Journal of Analytic Theology 
gone away. John Carriero (2009), in his recent lengthy commentary on the Meditations, repeats the charge in his analysis of the Third Meditation. Here I shall argue that the charge is unjustified on all counts. Baldly stated, Descartes's notion of aseity is no different (with one slight qualification) than the negative sense of aseity endorsed by his Scholastic predecessors-especially Aquinas. Understanding this not only helps in clarifying the overall picture of Cartesian causality but also aids in seeing how commentaries on the Meditations, old and new, have obscured it.

In $\S 1$, I introduce the concept of aseity and briefly explain why both Descartes's contemporaries and Carriero think the positive aseity charge is justified. $\S 2$ contains an argument, directed at Carriero's recent version of the charge, for (i) why the theistic proof from which the charge is derived does not need a positive notion of aseity to go through, and (ii) why reading positive aseity into the argument makes the proof incoherent. This alone, of course, does not show decisively that Descartes does not endorse positive aseity; at best it shows that the theistic proof in question is coherent. But in §3 I lay out Descartes's refined conception of aseity in a way that shows the charge from his contemporaries (and Carriero) to be misguided. Despite some apparently damning passages, closer analysis reveals that Descartes rejects positive aseity of the sort attributed to him by his contemporaries. As it turns out, then, Cartesian aseity is nothing (much) new, although it innovates on Aquinas in an interesting way. ${ }^{2}$

\section{The Positive Aseity Charge Made Explicit}

For my purposes, it is best to think of the Third Meditation as containing two proofs for God's existence. There are certainly two arguments given, and the extent to which they are intended to relate has no bearing on the force of my argument. Descartes seems to suggest that the point is not an important one, as he sometimes claims that he intended the second argument to be "a more thorough explanation" of the first argument (First Replies, AT 7:106; CSM 2:77), while elsewhere referring at other times he refers to them as two separate proofs (May 2, 1644 Letter to Mesland, AT 4:112; CSMK 231). At any rate, the second argument-from which the positive aseity charge is drawn- more or less stands on its own, but a brief review of the first argument is instructive.

After classifying different types of thoughts and turning to the subclass of ideas, Descartes presents his causal principle-that the cause of a given idea must have as much reality formally as the idea has objectively. ${ }^{3}$ Ideas that exist "objectively" as representations in the mind are to be thought of as effects of things

\footnotetext{
${ }^{2}$ As a bit of foreshadowing, it is Descartes's use of formal causation-which Aquinas lacks - that makes his notion of aseity both innovative with regard to Aquinas's but ultimately remarkably similar to it. 3 This principle has been given different names, e.g., the "cognitive causal principle" by Carriero (2009, 175f), and the "containment axiom" by Tad Schmaltz $(2008,49)$. I will just refer to it generically as the causal principle. The basic idea is that effects get their reality from their causes. Some effects are material (or "formal") while others, e.g. ideas, exist in the mind (or "objectively"). As such, any cause must have at least the amount of "reality" as any effect it might produce.
} 
that have actual (or "formal") existence in the world. Noting this, what Descartes seeks is the "efficient and total cause" of the ideas in his mind (AT 7:40; CSM 2:28). Since most ideas do not have that much objective reality (however "much" is to be quantified), Descartes has little difficulty sorting out the causal options for where they could be derived. The idea of God, however, has infinite objective reality; ${ }^{4}$ given the causal principle, then, the efficient cause of that idea must have infinite formal reality. After canvassing some options Descartes decides that no entity could have the requisite infinite formal reality except God. Since God is the only possible candidate for being the efficient cause of the idea of God, and since Descartes indeed has the idea of God, the obvious conclusion to be drawn is that God must exist.

Once it is resolved that God must be the cause of his idea of God, a slight doubt remains for Descartes when not contemplating the argument just given ("when I relax my concentration" (AT 7:47; CSM 2:32)). He immediately turns to the task of discovering the (efficient) cause from which his present existence as a thinking thing can be derived. After all, it is Descartes himself who has the idea of God, and so it is important for his purposes to know with certainty if he could exist if God does not (AT 7:48; CSM 2:33). What follows this thought is what I am calling the second argument and is the source of the positive aseity charge.

Understanding the charge does not require rehearsing the argument in its entirety, but a few points are worth noting up front. Once it is shown that he could not have derived his existence from himself, Descartes naturally concludes that his existence must be derived from something else. Not just anything else will do, however; the cause must be "itself a thinking thing" that possesses "the idea of all the perfections which I attribute to God" (AT 7:49; CSM 2:34). The reason for this-that a cause must contain at least as much reality as its effects-was established in the first argument. We may continue to inquire into the efficient cause of that cause, and so on, until we reach a cause that does in fact derive its existence from itself; this is existence $a$ se. Consider Descartes's comment on the causal chain:

In respect of this cause one may again inquire whether it derives its existence from itself or from another cause. If from itself, then it is clear from what has been said that it is itself God, since if it has the power of existing through its own might, then undoubtedly it also has the power of actually possessing all the perfections of which it has an idea - that is, all the perfections which I conceive to be in God. If on the other hand, it derives its existence from another cause, then the same question may be repeated ... until eventually the ultimate cause is reached, and this will be God. (AT 7:40-50; CSM 2:34; italics mine)

The central claim here is that any cause that can derive its existence from itself must be God, for nothing else could have the power to exist "through its own might" (AT

\footnotetext{
${ }^{4}$ Ideas that serve as representations of "finite substances" have some finite degree of objective reality, but the idea of an infinite God must have an infinite degree of objective reality (AT 7:40; CSM 2:28). The relation between formal and objective reality plays an important role in Descartes's argument, but it is too complex to fully treat here. See Lawrence Nolan and Alan Nelson (2006).
} 
7:50; CSM 2:34). ${ }^{5}$ Keeping this claim in mind, the positive aseity charge can now be formulated explicitly. The following is an exhaustive list of potential causal explanations for God's existence:

(1) God is caused by another

(2) God is self-caused

(3) God is uncaused

God does not exist a se if his existence is caused by another, and so (1) has no relevance here. But given that Descartes is concerned in the second argument with finding the efficient cause of his (Descartes's) continued existence, the above list is too ambiguous. It can be clarified by reformulating (2) and (3) in terms of two narrower notions of aseity:

$\left(2^{*}\right)$ God is efficiently self-caused

$\left(3^{*}\right)$ God has no efficient cause

The positive aseity charge is that Descartes's argument is an endorsement of $(2 *)$. The traditional Thomistic, or "negative," notion of aseity is variously stated along the lines of either (3) or ( $\left.3^{*}\right) .6$ If Descartes does in fact hold $\left(2^{*}\right)$, then he is introducing a radical new notion of aseity, since $\left(2^{*}\right)$ is inconsistent with both (3) and (3*). (Importantly for my argument below, note also that (3) entails ( $\left.3^{*}\right)$, but the reverse is not true.)

With respect to Descartes's contemporaries, the charge of positive aseity is issued almost immediately by Caterus in the First Set of Objections:

The phrase 'from itself' has two senses. In the first, positive, sense, it means 'from itself as from a cause.' What derives existence from itself in this sense bestows its own existence on itself; so if by an act of premeditated choice it were to give itself what it desired, it would undoubtedly give itself all things, and so would be God. But in the second, negative sense, 'from itself' simply means 'not from another'; and this, as far as I remember, is the way in which everyone takes the phrase. (AT 7:95; CSM 2:68)

From Caterus's view, Descartes is endorsing divine aseity in the positive sense of $\left(2^{*}\right)$ above, or "from itself as from a cause." It is not hard to see, by looking at the way Descartes sets up his argument, why Caterus thinks this. Descartes is concerned with finding the efficient cause of his continued existence, the source from which his continued existence is derived. Once we follow the causal chain (in fact, we need only go one step), we arrive at the "ultimate cause," God. Since Descartes is initially seeking a source from which his existence can be derived, it is natural to assume that the terminus of the causal chain-God-must derive his existence from himself in the

5 The reason for this latter claim will become evident in the next section.

${ }^{6}$ Carriero attributes (3) to Aquinas, but Aquinas only explicitly endorses (3*) (at least in the context of the Five Ways, as we'll see below in §2). 
same way-in this case as an efficient cause. So, if one derives one's existence from oneself, then one causes oneself (i.e., "from itself as from a cause").

But Caterus further supposes that Descartes's causal argument is directly analogous to the one given by Aquinas's Second Way (AT 7:94; CSM 2:68). ${ }^{7}$ Aquinas, however, makes use of aseity only in the negative sense of $\left(3^{*}\right)$, for the Second Way concludes that God is the "first efficient cause."8 In Caterus's formulation above, this is aseity as in "not from another." 9 Caterus is thus charging Descartes with adding something unnecessary to his causal argument. That is, given that the arguments from Aquinas and Descartes take "exactly the same approach," and given that Aquinas's argument succeeds with only the negative notion of aseity, Descartes's positive notion is too strong. ${ }^{10}$

While Descartes does not, in fact, endorse the positive aseity claim $\left(2^{*}\right)$ that Caterus attributes to him, the ambiguity with which he responds to Caterus only adds fuel to the fire:

[T] he negative sense of the phrase 'from itself' comes merely from the imperfection of the human intellect and has no basis in reality. But there is a positive sense of the phrase which is derived from the true nature of things, and it is this sense alone which is employed in my argument. (AT 7:110; CSM 2:79; italics mine)

This initial response to the charge looks to be an explicit sanctioning of positive aseity. Given that it was circulated to other commentators along with the manuscript of the Meditations, any future commentator had the raw material for making a supportable prima facie case that Descartes is introducing a novel, positive notion of aseity. For example, in the Fourth Set of Objections Arnauld attributes to Descartes the same notion of aseity that Caterus does, only this time the charge comes with an accompanying argument against the coherence of positive aseity as applied to an infinite being. Two claims are made. The first is that if God derives his existence from himself in the positive sense-as an efficient cause-then God must have created himself; the second is that thinking of God as self-preserving in a causal sense collapses into the claim that God created himself, because preservation just is continual re-creation (AT 7:212; CSM 2:149). ${ }^{11}$ Both claims make positive aseity seem

\footnotetext{
${ }^{7}$ Descartes resists this comparison and claims that Caterus has put him in "an unfortunate position" in making it. See AT 7:106; CSM 2:77.

8 Thomas Aquinas, Summa Theologiae I, q.2, a.3. God's place as the "first efficient cause" might be thought not to equate to $\left(3^{*}\right)$, since God still could serve as his own efficient cause; but Aquinas rules this out in the Third Way.

${ }^{9}$ In other words, when considering efficient causation, "not from another" just means "not efficiently caused by another." Caterus explains this in the passage immediately following the one just quoted.

10 Interestingly, Caterus seems to think that even Aquinas's argument is a bad one, in that it cannot establish that God "embraces all things and is infinite" (AT 7:95; CSM 2:68). However, an analogous claim cannot be made against Descartes's second argument, since God's infinitude has already been established in the first argument.

11 Here Arnauld is endorsing Descartes's doctrine of divine concurrence (or continual creation)-the thesis that the efficient causal act of creating a thing and the act of sustaining or preserving that thing in existence are only conceptually distinct (AT 7:49; CSM 2:33). Note that "divine concurrence" has
} 
absurd, since anything that creates itself must exist before it begins to exist. Arnauld's version of the charge is thus a much stronger response than that of Caterus insofar as it serves as a straightforward refutation of the coherence of positive aseity. I will consider Descartes's reply to Arnauld in $\S 3$.

Turning now to Carriero's recent attribution of positive aseity to Descartes, it is clear that Cartesian aseity is characterized in a similar way to the formulation by Caterus. Carriero $(2009,197)$ takes "a being that is causally responsible for its existing" to be a being that is "self-sustained." A bit earlier Carriero claims that "Descartes's insistence that we know God to be a se... in some positive sense ... implies that we cognize God as a self-caused being" $(2009,196)$. The broad picture here is that Carriero takes Descartes to be distancing himself from the negative philosophical theology of his predecessors, with Aquinas being exhibit $A$. For Aquinas (according to Carriero), it is only via the senses that we can establish that God is; and we can only establish what God is in a minimal sense when cognizing in accordance with the via negativa. Take Aquinas's First Way as an example: the argument begins with the sensible observation of motion and concludes that there must be a first mover to the series of movers; thus we get the bare nominal characterization of God as the "unmoved mover" - a claim equivalent to the notion of negative aseity in (3). ${ }^{12}$ Descartes, on the other hand, takes our cognition of God to run in the opposite direction: we can have a content-rich idea of God before any arguments for his existence are given; that is, we can grasp at least part of God's essence (what God is) and still have the advantage of being able to offer arguments that God is (Carriero 2009, 173). The first theistic proof in the Third Meditation serves as an example of this. Descartes starts the argument with the claim that he is in possession of the idea of God and proceeds to prove that God exists on the basis of that idea taken together with his causal principle. To further support Carriero's contrasting picture of how Descartes and Aquinas view our cognition of God, note that even if Descartes accepts Aquinas's methodology, he cannot lay claim (yet) to an analogous way of cognizing God (via the senses). For, at the place in the Meditations where the first (and second) theistic proof is given, the reliability of the senses is still in doubt.

Building on the claim that Descartes is attempting to distance himself from the methodology of his Scholastic predecessors in general, and Aquinas in particular, Carriero suggests a reading of the second argument that necessitates the use of positive aseity. This difference is initially brought out by the fact that Aquinas and Descartes have different explananda from which they begin their respective arguments (see Carriero 2009, 198-207). On Carriero's reading, Descartes's second argument is best contrasted with Aquinas's First Way. There, Aquinas is concerned with giving a causal explanation for motion in the world (the explanandum) and eventually settles on God as being the "unmoved mover" who is ultimately causally

been (and is) used in ways that differ from Descartes's. At any rate, this motivates the positive aseity charge from Arnauld: if God is self-sustaining then God must be the efficient cause of himself.

12 See Carriero (2009, 169-174). For Aquinas's First Way, see Summa Theologiae I, q.2, a.3. It is important to note that Carriero is wrong about this. The First Way concludes not that God is the "unmoved mover" but that God is the "first mover, moved by no other." This is the difference between affirming (3) and affirming ( $\left.3^{*}\right)$. 
responsible for that motion. ${ }^{13}$ Descartes, however, begins his second argument from the desire to account for his present (or continued) existence (the explanandum) and concludes that God - who has the power of existing "through his own might" - is the only causal explanation for this.

Carriero takes the fact that the two arguments are concerned with different explananda to be a result of the two thinkers operating with different causal principles. The causal principle at work in the First Way is restricted to accounting for the cause(s) of things that are moving in the world; since God turns out to be unmoved, God is exempt from needing a causal explanation. Descartes's argument, by contrast, assumes a universal causal principle by which the continued existence of anything is in need of a causal explanation (Carriero 2009, 217). Carriero is right about this. As Descartes notes in responding to Caterus in the First Replies: "the light of nature does establish that if anything exists we may always ask why it exists; that is, we may inquire into its efficient cause, or, if it does not have one, we may demand why it does not need one" (At 7:108f; CSM 2:78; italics mine).

This feature of Descartes's second argument-that it operates with a different causal principle-leads Carriero to suggest that Descartes must make use of positive aseity because his argument could not work otherwise. The reason is that there is no move open to Descartes analogous to the one made by Aquinas that can get him God's existence $a$ se in the negative (Thomistic) sense. Carriero summarizes this point nicely:

And while it makes sense to think, as Aquinas does, that there can be an unmoved mover or an uncaused cause ... it is not clear what would be the analogue for Descartes's situation: if one starts from the idea that all existing requires sustaining ... then the most immediate analogue to a mover that is unmoved because it does not move or change would be a sustainer that is unsustained because it does not exist. But this seems incoherent. (217)

Put differently, if everything (including God) is in need of a causal explanation, then Descartes cannot claim that God is uncaused (as in (3)) or efficiently uncaused (as in $\left(3^{*}\right)$ ), for both claims violate the universal causal principle. So while Caterus thinks that Descartes needs only the negative notion of aseity $\left(3^{*}\right)$ to make his causal argument go, Carriero thinks that Descartes cannot make his argument go without the stronger, positive notion of $\left(2^{*}\right)$. If either is right, however, the attribution of positive aseity to Descartes's argument seems justified. In the next two sections, I argue that both Carriero and Caterus are mistaken. First, contra Carriero, I suggest that Descartes does not need the positive notion of aseity and, moreover, that the second argument sinks into incoherence if positive aseity is read into it. In $\S 3$, once the nuance of Descartes's notion of aseity is clarified, it will be evident that he has no use for the positive notion of $\left(2^{*}\right)$. That is, once the structure of the second argument is properly understood it becomes evident that Cartesian aseity is (almost) no

${ }^{13}$ Summa Theologiae I, q.2, a.3. Again, Carriero is wrong about how the First Way concludes. See note 12. 
different from Thomistic aseity.

\section{How the Second Argument Works: Efficient Causation and Divine Concurrence}

Recall that Carriero takes Aquinas and Descartes to be offering theistic proofs with different explananda serving as starting points; from this, he takes Aquinas and Descartes to be working with different causal principles; and from this, he concludes that Aquinas needs only the negative notion of aseity while Descartes needs the stronger positive notion to make his second argument coherent. This latter claim, however, does not follow from the first two. Carriero is right that Aquinas and Descartes are working from different explananda; for Aquinas, the phenomenon in need of a causal explanation is motion in the world (the First Way) and the observation of efficient causation itself (the Second Way); for Descartes, the phenomenon is his preserved existence. As I see it, however, Carriero's claim that the explananda are different is largely irrelevant to the task of figuring out how Descartes conceives of divine aseity. The important thing to note in both arguments is that they are concerned with providing an efficient causal explanation for their respective explananda. ${ }^{14}$ Recall my earlier claim that in the second argument Descartes is seeking an efficient cause for his continued existence. ${ }^{15}$ Descartes makes this point explicit in the Fourth Set of Replies. Once Arnauld has repeated Caterus's positive aseity charge, Descartes begins his response with a word about the value of a causal theistic proof:

Now if the term 'cause' serves to demonstrate the existence of God, it can hardly be more useful; and if it is impossible to achieve complete clarity in the proof without it, the term can hardly be more necessary. But I think it is clear to everyone that a consideration of efficient causes is the primary and principal way, if not the only way, that we have of proving the existence of God. We cannot develop this proof with

\footnotetext{
${ }^{14}$ Descartes is concerned with his sustained existence (an effect) only in virtue of being concerned with finding a causal explanation for it. That Descartes exists has already been established in the "cogito" argument of the Second Meditation. In the present argument his task is finding out the causal mechanism responsible for his sustained existence. Consider his comment to Caterus in the First Replies: "the question I asked concerning myself was not what was the cause that originally produced me, but what is the cause that preserves me at present" (AT 7:107; CSM 2:77; italics mine).

${ }^{15}$ Although the argument is formulated in terms of finding a "cause" rather than an "efficient cause," there is no other plausible option for what sort of cause Descartes could be seeking. One reason is that Descartes sees his second argument as a natural follow-up to the first causal argument (AT 7:106; CSM 2:77). In the setup for the first argument, Descartes is more explicit in inquiring into the "efficient and total cause" of his idea of God (AT 7:40; CSM 2:28). If the first argument is concerned with finding the efficient cause of the idea of God, and if the second argument is supposed to serve as a follow-up to or explanation of the first, it's natural to conclude that the second argument, too, is concerned with efficient causation. Moreover, as Tad Schmaltz argues (convincingly) in his commentary on Cartesian causation, Descartes had largely abandoned a full-blown Aristotelian theory of causation to the extent that he understood causation "almost exclusively" in terms of efficient causation (2008, 4ff).
} 
precision unless we grant our minds the freedom to inquire into the efficient causes of all things, even God himself. (AT 7:238; CSM 2:166).

Since considering efficient causation is perhaps the only way to prove that God exists, there is no reason to doubt that the second argument-itself a theistic proof-is concerned with efficient causation.

Aquinas's causal proofs are likewise concerned with efficient causation. Compare Descartes's second argument to Aquinas's Second Way, as Caterus does. ${ }^{16}$ Aquinas begins his Second Way as follows: "We find that there is an order of efficient causes in the observable world. Yet we never observe, nor even could, something efficiently causing itself. For this would mean that it preceded itself, which it cannot do." 17 After ruling out the possibility of an infinite regress of causes, Aquinas concludes that there must be a first cause. As I see it, Caterus is not too far off the mark when comparing this argument to Descartes's second argument. Descartes begins with a phenomenon in need of an efficient causal explanation (his presently existing), systematically rules out all of the options (except God) that could play that explanatory role (including an infinite causal regress), and concludes that God must be the efficient cause from which his (Descartes's) continued existence is derived (AT 7:48f; CSM 2:33f). This makes Descartes's argument nearly parallel in structure to the Second Way. Aquinas wants an explanation for the existence of every efficient cause and settles on God (i) as being the efficient cause of everything but himself and (ii) as a being that is not the efficient cause of himself. (God's nature as an intrinsically necessary being precludes this, as Aquinas purports to demonstrate in the Third Way.) Likewise, Descartes wants an efficient causal explanation for his own existence and settles on God (i) as being that efficient cause and (ii) as a substance that needs no efficient cause. ${ }^{18}$ Given that the two arguments run parallel in this way, it is no longer plausible to suppose (as Carriero does) that Descartes's argument needs the positive notion of aseity to be coherent while Aquinas's argument needs only the negative notion. ${ }^{19}$ After all, Aquinas's first two Ways likewise seek an efficient causal

${ }^{16}$ Caterus claims that Descartes's takes "exactly the same approach" as Aquinas's "way based on the causality of the efficient cause" - the heading of the Second Way (AT 7:94; CSM 2:68). However, for some untold reason(s), Carriero finds it more helpful to compare Descartes's second argument with the First Way.

${ }^{17}$ Summa Theologiae I, q.2, a.3. The translation I'm using is Brian Davies and Brian Leftow (2006).

18 (ii) is difficult to pull from the second argument without the aid of the rest of Descartes's corpus. I argue for it in the next section.

19 Perhaps another reason why Carriero puts so much stock in the claim that Aquinas and Descartes are starting from different explananda is that he ignores this point. In arguing for the difference(s) in the way that Aquinas and Descartes go about formulating their causal arguments, Carriero compares Descartes's second argument not to Aquinas's Second Way, as Caterus does, but to his First Way (the First Way argues for God's existence based on the motion, or change, that our senses clearly perceive in the world). Also, Carriero's reconstruction of Descartes's second argument leaves out all causal language in favor of words like "sustainer" and "self-sustained," neither of which is used by Descartes. This is supposed to lend support to the claim that Descartes begins his argument "from a felt need to account for the metaphysical differences between staying in existence and falling out of existence." As I have just argued, however, this has little relevance. What is important is that Descartes is concerned with his continued existence only in virtue of seeking an efficient causal explanation for that phenomenon. 
explanation for some phenomena, but neither concludes that God serves as the efficient cause of his own existence (that is, neither concludes with anything like $\left(2^{*}\right)$ ). Descartes's argument operates in the same fashion and, as such, doesn't need a notion of positive aseity to go through. (Of course, Descartes owes an explanation for why God is the one exception to the rule that everything can be given an efficient causal explanation, but this explanation is absent in the Third Meditation. I'll return to this latter point in the next section.)

Despite Descartes's argument not necessitating the use of positive aseity to function, the worry remains that he makes use of it nonetheless. I suggest that an understanding of (what I'm calling) Descartes's Doctrine of Divine Concurrence at play in the second argument can dispel this worry. In the second argument Descartes settles on God as the efficient cause of his (Descartes's) present, and sustained, existence. There are a few reasons why Descartes concerns himself with his present or sustained existence rather than with (as Aquinas does) his existence simpliciter. One is that he takes the question of the cause that preserves something at the present time to avoid the difficulty associated with dealing with an infinite regress of causes (see AT 7:107; CSM 2:77). ${ }^{20}$ The other reason, and the one more relevant for my purposes, is that he takes creation and preservation to be only conceptually distinct. ${ }^{21}$ This is due to the Doctrine of Divine Concurrence-the view that God's sustaining power is necessary for the continued persistence of each created thing (AT 7:49; CSM 2:33). ${ }^{22}$ The role of the Doctrine in the second argument is as follows: I might have always existed, in which case there is no need to hunt for an efficient cause of my existence. But, says Descartes, "the same power and action are needed to preserve anything at each individual moment of its duration as would be required to create that thing anew if it were not yet in existence" (AT 7:49; CSM 2:33). So, even if I have always existed, something must be powerful enough to sustain my existence at any given moment-a power that I certainly lack. Eventually, of course, Descartes's conclusion is that God is the only option for being an efficient cause that has the power to sustain all things, for God's power is great enough that he can exist "through [his] own might" (AT 7:49f; CSM 2:34).

To recap: I cannot serve as the efficient cause of my sustained existence, but God can, for he has the power to exist through his own might. This, it should be clear, is where Caterus pulls the positive aseity charge; it looks as though God is claimed to

${ }^{20}$ If the succession of events is diachronic, as in the case of Caterus's reading of Thomistic arguments, then there is no principled reason to suppose that such a series could not be infinite. If the causal chain is synchronic, as is the case when Descartes concerns himself with his presently existing, then the causal chain cannot be infinite. I have no idea why Descartes holds this view, but see AT 7:107; CSM 2:77-78.

21 "Conceptually distinct," for Descartes, is another way of saying that two things are identical: "since a substance cannot cease to endure without also ceasing to be, the distinction between the substance and its duration is merely a conceptual one" (AT 8A: 30; CSM 1:214).

${ }^{22}$ Schmaltz calls this the "conservation axiom." Perhaps the clearest statement of the doctrine is in the Letter to Hyperaspistes, August 1641: "there is no doubt that if God withdrew his concurrence, everything which he has created would immediately go into nothing; because all things were nothing until God created them and lent them his concurrence" (AT 3:429; CSMK 193). Descartes takes the doctrine of divine concurrence to be obvious-a view "which all metaphysicians affirm as a manifest truth" (AT 7:369; CSM 2:254). 
be the efficient cause of himself (as in (2*), i.e., existence "from itself as from a cause"). The problem can be put in a way similar to the objection from Arnauld. If preservation, or sustaining, is only conceptually distinct from creating, and if God sustains his own existence, then, by implication, God created himself.

Arnauld is certainly right that a thing cannot cause its own existence by creating itself (AT 7:212; CSM 2:149). ${ }^{23}$ What we have, then, is a reason not to attribute positive aseity to Descartes's conception of God. Given that the Divine Concurrence, when combined with positive aseity, leads to the untoward consequence that God is efficiently self-caused, we should reject the charge against Descartes for the reason that it makes his second argument incoherent. Descartes's decision to formulate his second argument in terms of his present existence might, as he claims, avoid the problem of accounting for an infinite causal regress in the way that Aquinas has to, but only at the expense of setting himself up for the greater problem of explaining how his argument does not sink into incoherence. This is a task that Descartes fails to take up in the Meditations proper. But, as I argue in the next section, there are plenty of textual reasons to take Cartesian aseity to be (roughly) the same notion as the negative aseity employed by Aquinas.

\section{Formal Causation as Divine Aseity}

We've seen that the Doctrine of Divine Concurrence at play in the second argument leads to absurdities when combined with the positive aseity asserted in $\left(2^{*}\right)$-that God is efficiently self-caused. A worry still remains that the charge from Caterus and Arnauld is not empty after all. Perhaps the second argument is as incoherent as Arnauld claims; perhaps Descartes did have something along the lines of $\left(2^{*}\right)$ in mind when he claims that God exists "through his own might." Descartes seems to give this impression at times, particularly in his initial reply to Caterus:

I did not say that it was impossible for something to be the efficient cause of itself. This is obviously the case when the term efficient is taken to apply only to causes which are prior in time to their effects, or different from them. But such a restriction does not seem appropriate in the present context.... However, the light of nature does establish that if anything exists we may always ask why it exists; that is, we may inquire into its efficient cause, or, if it does not have one, we may demand why it does not need one. Hence, if I thought that nothing could possibly have the same relation to itself as an efficient cause has to its effect, I should certainly not conclude that there was a first cause .... However, I do readily admit that there can exist something which possesses such great and inexhaustible power that it never required the assistance of anything else in order to exist in the first place, and does not now require any assistance for its preservation, so that it is, in a sense, its

${ }^{23}$ Arnauld's reason is that for something to create itself it must be around before it exists, which is incoherent. Aquinas agrees; see his Second Way, Summa Theologiae I, q.2, a.3. 
own cause; and I understand God to be such a being. (At 7:108f; CSM 2:78; italics mine)

This looks like a straightforward endorsement on the part of Descartes that God exists positively $a$ se as the efficient cause of himself. In the case of effects that fall temporally after their causes, it makes no sense to say that they could serve as their own causes, for, as Arnauld notes, this entails that they would have existed before they exist-which is absurd. But in the "present context"-where an eternally existing God is concerned-temporal restrictions are irrelevant to causation. A few paragraphs later Descartes is more explicit. Still responding to Caterus, Descartes says of God that "we are quite entitled to think that in a sense he stands in the same relation to himself as an efficient cause does to its effect, and hence that he derives his existence from himself in the positive sense" (AT 7:111; CSM 2:80; italics mine). In other words, it looks as though God is efficiently self-caused.

I'll argue in this section, however, that Descartes in fact does not affirm that God is efficiently self-caused. Instead, he employs the notion of formal causation to escape the charge from Caterus, albeit not until much later. Before showing how Descartes does this, it makes sense to ask: if we must appeal to formal rather than efficient causation to make sense of God's aseity, why didn't Descartes just say so in the Meditations? Doing so would have cleared up a lot of confusion that has persisted to the present. Later on in the Fourth Set of Replies, Descartes in fact tells us why he did not make the distinction between formal and efficient causation: "I did not explain this point in my Meditations, but left it out, assuming it was self evident" (AT 7:239; CSM 2:167). Just prior, we are told that "those who follow the sole guidance of the natural light" will be in a similar epistemic situation! As I'll show below, it is a proper understanding of God's essence that gives us the tools to understand the distinction between efficient and formal causation. ${ }^{24}$ Descartes claims here and elsewhere (AT 7:69; CSM 2:47) that the nature of God's essence is self-evident-at least to those who follow the "natural light."

No doubt the confusion of later commentators (especially Arnauld) is attributable to Descartes's failure to sufficiently explain his nuanced account of aseity to Caterus. It isn't until the Fourth Replies that Descartes makes it clear that he does not have the positive aseity of $\left(2^{*}\right)$ in mind. Instead, both the lengthy quote above (CSM 2:78) and the second argument from the Third Meditation begin with claims about efficient causation and end with a set of claims about God's causal power-as the efficient cause and sustainer of everything else apart from himself and as not requiring an efficient cause to account for his own existence. ${ }^{25}$ Another look at the argument will clarify this.

Both Descartes's second argument and Aquinas's Second Way begin from the assumption that we ought to be able to give an efficient causal explanation for some phenomenon. Descartes tells us further that we are permitted to ask for an efficient causal explanation of all phenomena-including God's existence (AT 7:238; CSM

\footnotetext{
${ }^{24}$ Descartes also makes this explicit just prior to the passage just quoted.

${ }^{25}$ Again, this latter claim, as in Aquinas's Second Way, is due to God's nature. The textual argument for this is given below.
} 
$2: 166)$. Noting how the two arguments proceed is important for seeing that Descartes affirms, with Aquinas, that God exists $a$ se in the negative sense of $\left(3^{*}\right)$. In both cases we start from a phenomenon in need of an efficient causal explanation. We then follow the causal chain (for Descartes, only one step; for Aquinas, some finite number of steps) until we reach a cause that itself needs no efficient cause. In both arguments this causal terminus is God.

But why think, as both arguments claim, that everything is subject to an efficient causal explanation except God? Aquinas settles the matter immediately in his Third Way: "This means that we are forced to posit something which is intrinsically necessary, owing its necessity to nothing else"26 — this is the negative aseity expressed by (3). God's essence turns out to be such that there is not even the possibility of an efficient causal explanation for it. If an entity exists necessarily then, a fortiori, that entity exists $a$ se in the negative sense of (3). Descartes eventually reaches roughly the same conclusion, but his approach is more roundabout, for his universal causal principle demands that God's existence is still in need of some sort of causal explanation; moreover, the second argument does not deal with God's necessity directly, as Aquinas's Third Way does (we don't get that until the ontological proof in the Fifth Meditation ${ }^{27}$ ). That is, while Aquinas infers that God's nature is such that no causal explanation for God's existence is available, Descartes needs a reason for making that assertion. Indeed, we cannot even imagine "anything deriving existence from itself without there being some reason why it should exist rather than not exist" and so we should "interpret 'from itself' in a causal sense" (AT 7:112; CSM 2:80). And so God's (negative) aseity must be explained via some intermediate causal step.

The conclusion of Descartes's second argument is that there must be a being that can exist "through its own might" and that this being must be God. The argument is repeated in the Principles of Philosophy, clarifying that what it means for God to have the power to keep himself in existence is that "he requires no other being to keep him in existence" (Part One, Art. 21; AT 8a:13; CSM 1:200). This is straightforward aseity in Caterus's negative sense of "not from another". The causal explanation for God's aseity, as for Aquinas, turns out to be a matter of knowing God's essence.

Descartes tells us that the causal explanation for God is formal, not efficient. God has the power to preserve his existence just because God's essence makes it so that he could not fail to exist. God's essence, that is, functions as the formal cause for his existence. Two passages are instructive here. The first is from a letter to Mersenne in which Descartes clarifies some of the ambiguous wording from his Reply to

\footnotetext{
${ }^{26}$ Summa Theologiae I, q.2, a.3. Italics mine.

${ }^{27}$ In the first argument from the Third Meditation Descartes does conclude that God necessarily exists but, in the two instances there in which Descartes lists the divine attributes contained in his idea of God, necessity is left out each time. In the first instance, we get the idea of a "supreme God, eternal, infinite, <immutable,> omniscient, omnipotent and the creator of all things that exist apart from him" (AT 7:40; CSM 2:28); In the second instance, Descartes states that "by the word 'God' I understand a substance that is infinite, <eternal, immutable,> independent, supremely intelligent, supremely powerful, and which created both myself and everything else" (AT 7:45; CSM 2:31). In the Fifth Meditation proof, however, necessary existence is a stated property of God; also, Descartes proclaims that God's existence-as a being "to whose essence alone existence belongs"—is self-evident (AT 7:69; CSM 2:47).
} 
Caterus:

[At] the words 'Hence if I thought that nothing could somehow have the same relation to itself ...' please put in the margin 'Note that these words mean only that there may be a thing whose essence is such that it needs no efficient cause in order to exist' .... A little further on, at the words 'Although God has always existed since it is he who in fact preserves himself', put in the margin 'It should also be noted that "preservation" here must not be understood to be the kind of preservation that comes about by the positive influence of an efficient cause; all that is implied is that the existence of God is such that he must always exist.' (AT 3:335-336; CSMK 175-176) ${ }^{28}$

God's always existing is a consequence of God's power of self-preservation which, in turn, is a consequence of God having an essence of the sort that it needs no efficient causal act to bring it into existence. Put the other way around, God's essence is the formal causal explanation for his ability to exist through his "own might," the latter being the efficient causal explanation for Descartes's present existence in the second argument. The second passage is more explicit:

[Y]ou say 'God is the cause of himself.' Several people have in the past misinterpreted this phrase, and hence it would appear to require some such explanation: 'For something to be the cause of itself is for it to exist through itself [ $a s e]$, and to have no other cause than its own essence, which may be called a formal cause.' (Letter to ***, March 1642; AT 7:546; CSM 2:213)

God's having an essence such that it could not fail to be the case that God exists means (inter alia) that God is a necessary being. Of course, this is consistent with the conclusions of the first theistic argument in the Third Meditation (that God exists necessarily) and the ontological proof from the Fifth Meditation. But it is also in accord with Aquinas's characterization of God's essence in his Third Way. Thus Descartes is operating, in his second argument, with the same (negative) notion of aseity that Aquinas employs in his causal arguments (the first two Ways). The difference is that Descartes's argument is more thorough in the sense that he provides a causal explanation for God's existence without bringing to bear, at least in the immediate context of the argument, the language of necessity.

However, Descartes's notion of aseity is not identical to Aquinas's. The Thomistic notion can be interpreted as either the claim that God is uncaused (3) or efficiently uncaused $\left(3^{*}\right)$, depending on which Way is being considered. Given his claims about divine formal causation, Descartes can affirm that God is efficiently

\footnotetext{
${ }^{28}$ Italics mine. Here Descartes looks to be making an exception for God. His doctrine of divine concurrence tells us that the persistence of every created thing depends on the efficient causal activity of God; but here, the persistence of God is explicitly not the sort of persistence that depends on efficient causation, since God is uncreated.
} 
uncaused $\left(3^{*}\right)$, thus agreeing with Aquinas. But his universal causal principle prevents Descartes from affirming that God is uncaused per se, as in (3). Recall that Descartes's need for a causal explanation is universal in the sense that he thinks we ought to extend our causal inquiry as far as we can-even to the cause of God's existence. This is why, once it is stated in the second argument that God exists a se, Descartes does not take it to mean that God has no cause at all, but only that God has no efficient cause. If aseity just means 'not the efficient cause of oneself', then any attribution of aseity becomes trivial, for nothing can be the efficient cause of itself. ${ }^{29}$ Hence Descartes's suggestion that God's essence acts as a formal cause-a "kind of cause analogous to an efficient cause" (AT 3:336; CSMK 176).

Descartes blames the Scholastics for the narrow view of aseity as being concerned with only efficient causation. In a letter to Mersenne, again clarifying his response to Caterus in the First Replies, Descartes complains as follows:

I did not mean to say that 'Something could be its own efficient cause if "efficient" is taken in the strict sense'; I meant only that when we ask 'whether anything can exist "from itself"' the question must not be taken to concern 'efficient causality strictly so called, or it would be vacuous', as I said. It is because of the common scholastic axiom 'Nothing can be its own cause' that 'from itself' has not been taken in the appropriate sense. (AT 3:336; CSMK 3:176) ${ }^{30}$

Interestingly, the fact that aseity has not been understood in the appropriate sense turns out to be the original source of the positive aseity charge against Descartes. Recall Caterus's original formulation of the two sorts of aseity: positive aseity means "from itself as from a cause"; negative aseity means "not from another" (AT 7:95; CSM $2: 68)$. The problem with this formulation, from Descartes's view, is that Caterus is

${ }^{29}$ However, the limited scope of Aquinas's causal arguments (the first two Ways) dictates that his notion of aseity only refers to God's lacking an efficient cause. He cannot claim that God is uncaused until the Third Way.

30 This passage is one of many that we've seen in which Descartes gives Mersenne an amended or corrected reading for how he initially responds to Caterus. The view suggested by the argument of this paper is that Descartes all along has had this sophisticated and innovative notion of divine aseity that plays an important functional role in the Third Meditation. On this reading, the letter to Mersenne is simply an attempt to clarify this notion after so many commentators have been heretofore unable to make sense of it. But it's at least worth mentioning that there is an alternative possibility (albeit a less charitable one): that Descartes simply changed his mind, perhaps due to the scathing critiques of his peers. On the latter view, the letter to Mersenne is Descartes's way of backpedaling out of an untenable position in favor of a later-conceived tenable one. While Descartes is adamant that this is not what he is doing, it would not be opposed to the overall project of the Meditations. After all, the reason Descartes decided to publish the Objections and Replies along with the Meditations was so "that in consequence the truth will stand out all the better" (CSM 2:63 - translator's preface). Given the nature of the objections and Descartes's replies, such would require that at least somebody changes their mind(s)! At any rate, I'm inclined to take Descartes's word for it and accept the former reading, which has much going for it. This is especially so because (i) the causal proof in the Third Meditation sinks into incoherence without this notion of aseity, and (ii) because of its cohesion with other long-standing positions Descartes has committed himself to holding (e.g., the Doctrine of Divine Concurrence). (Thanks to two anonymous reviewers for discussing this.) 
working from the Scholastic notion that "cause" here refers only to "efficient cause." Once "cause" is broadened to include formal causation, Descartes can indeed say that God exists a se in the sense of "not from another," as in $\left(3^{*}\right)$, and in the sense of "from itself as from a cause"; for, if the formal cause of God's existence is his essence, then, a fortiori, God exists "not from another." That is, Descartes can affirm that God is selfcaused, as in (2), while denying that God is efficiently self-caused, as in (2*).

Given that the positive aseity charge claims that Descartes is endorsing $\left(2^{*}\right)$, his broadened notion of aseity gets him off the hook. When Descartes concedes to Caterus that he endorses positive aseity (AT 7:109-110; CSM 2:78-79), it is because he takes his broadened notion to be the only intelligible kind of aseity. What Descartes is not conceding is that he endorses aseity as in "from itself as from an efficient cause" - which is how Caterus and Arnauld take positive aseity to function. ${ }^{31}$ Thus when Descartes says that God is a being "which possesses such great and inexhaustible power that it . . . does not now require any assistance for its preservation, so that it is, in a sense, its own cause", the "in a sense" serves as a reference to formal causation (AT 7:109; CSM 2:78). As such, God exists "from itself as from a formal cause." This allows Descartes to affirm the same divine aseity as Aquinas (i.e., $\left(3^{*}\right)$ ), but he adds that $\left(3^{*}\right)$ is fully consistent with the claim that God is (formally) self-caused, as in (2). Fortunately for Descartes, this addition makes no claim to anything like the efficient self-causation posited in $\left(2^{*}\right)$-a thesis that Descartes rejects outright. This is affirmed in the Fourth Replies: "M. Arnauld . . . shows that God is not self-created or self-preserved by any positive influence of an efficient cause; and this I quite agree with" (AT 7:232; CSM 2:162). ${ }^{32}$

As a final recapitulation, the positive aseity charge asserts that Descartes's second argument contains the claim that God exists from himself "as from a cause"where "cause" is to be interpreted as "efficient cause" as in $(2 *)$. Caterus claims that this positive notion of aseity is superfluous; Arnauld claims that the notion is incoherent; and Carriero claims that it is necessary to make Descartes's argument work. I have argued, contra Carriero, that Descartes's second argument does not need a positive notion of aseity to function, and that the argument sinks into incoherence if aseity is construed along the lines of $\left(2^{*}\right)$. Furthermore, I have argued that Caterus is wrong to make the charge in the first place; he fails to understand that Descartes is working with a broadened notion of aseity in which "from itself as from a cause" includes formal causation. Further, Descartes's notion of aseity entails the Scholastic, negative notion of "not from another." In this way Descartes and Aquinas are affirming essentially the same thing-that God's existence relies on no force apart from God's essence. ${ }^{33}$

31 This is especially evident in Arnauld's formulation of the charge: "God cannot be thought of as deriving his existence 'from himself' in the positive sense, as if he had created himself in the beginning. For then he would have existed before he existed" (AT 7:212; CSM 2:149). Only efficient causes can be understood as creators of their effects; formal causes cannot.

32 This sentiment is echoed elsewhere in Descartes's corpus, e.g., in that God is uncreated and independent (AT 8a:26; CSM 1:211), and that necessity is contained in the idea of God (AT 8b:361; CSM $1: 306)$.

33 Thanks are due to Lex Newman, Stephen M. Downes, and Jonah Schupbach for thorough feedback on earlier drafts of this paper. 


\section{Bibliography}

Aquinas, Thomas. 2006. Summa Theologiae, Questions on God, translated by Brian Davies and Brian Leftow. Cambridge University Press.

Carriero, John. 2009. Between Two Worlds: A Reading of Descartes's Meditations. Princeton University Press.

Descartes, René. 1964-1976. Oeuvres de Descartes, edited by Charles Adam and Paul Tannery. J. Vrin/CNRS.

1985. The Philosophical Writings of Descartes. 2 vols, translated by John Cottingham, Robert Stoothoff, and Dugal Murdoch. Cambridge University Press.

- 1991. The Philosophical Writings of Descartes. Vollume III: The Correspondence, translated by John Cottingham, Robert Stoothoff, Dugal Murdoch, and Anthony Kenny. Cambridge University Press.

Nolan, Lawrence and Alan Nelson. 2006. "Proofs for the Existence of God." In The Blackwell Guide to Descartes' Meditations, edited by Stephen Gaukroger. Blackwell.

Schmaltz, Tad. 2008. Descartes on Causation. Oxford University Press. 